\title{
Financial Ecological Environment, Ownership Structure and the Financing Efficiency of New Energy Industry in China
}

\author{
Hairong Wang ${ }^{1,2, *}$ and Chengxuan Geng ${ }^{1}$ \\ ${ }^{1}$ School of Economics and Management, Nanjing University of Aeronautics and Astronautics, Nanjing, Jiangsu 211106, China \\ ${ }^{2}$ School of Economics and Management, Nanjing Institute of Technology, Nanjing, Jiangsu 211167, China \\ ${ }^{*}$ Corresponding author
}

\begin{abstract}
Financing efficiency is reflected in the ability of enterprises to integrate funds with the lowest cost and risk, and to use the integration of funds for bring the highest profits to the company in a specific macro environment. Its effective promotion cannot be separated from the external financial ecological environment and internal governance foundation. Take the sample of 132 listed companies of China's new energy industry from 2010 to 2016, then use a generalized DEA model which is based on panel data to measure its dynamic financing efficiency, and construct a systematic GMM model to empirically examine the impact of financial ecological environment and ownership structure on the financing efficiency of new energy industry, the research shows that the financing efficiency of new energy industry has obvious inertial effect and time cumulative effect, and it has entered a steady upward track, while there is still much room for improvement. The economic foundation and the level of financial resources are positively related to the financing efficiency of new energy industry. The influence of the legal honest environment and humanistic social environment on the financing efficiency of new energy industry is not yet obvious. The non-state-owned new energy listed companies with relatively dispersed equity in the eastern and central regions have higher financing efficiency, and the state-owned new energy listed companies with relatively concentrated equity in the western region have higher financing efficiency. It is necessary to further improve the benign development mechanism of capital financing and scientific allocation of new energy industry in allusion to the differences of the financial ecological environment and ownership structure of enterprises in different regions.
\end{abstract}

Keywords-financial ecological environment; ownership structure; financing efficiency; new energy industry

\section{INTRODUCTION}

With the rapid development of the economy and the continuous improvement of people's living standards, the economic demand for energy also increases continuously, and the contradiction between the supply and demand of traditional energy such as coal, oil, and natural gas has become increasingly prominent. Compared with traditional energy, new energy which is represented by solar energy, wind energy, hydro energy, biomass energy, geothermal energy, and ocean energy can not only alleviate the conventional energy supply shortage, provide a sustainable energy source for social and economic development, but also can fundamentally reduce environmental pollution, address climate change and improve the ecological environment, promote the transformation of economy and the mode of industrial growth. Many countries are developing new energy as an important part of energy strategy, provide solid technical support and industry foundation for the development and utilization of new energy.

As a technology-intensive and capital-intensive emerging industry, the investment of new energy industry in projects requires huge amounts of funds, especially in the scientific research and construction stage. The core is to improve the quality of financing. Therefore, this article introduces ecological thinking and measures the impact of financial ecological environment and internal governance factors on financing efficiency on the basis of dynamically measuring the changes in the financing efficiency of new energy industry, and seeks a integrated point for the improvement of financial ecological environment and internal governance reforms in new energy industry, in order to promote the effective ascension of the financing efficiency of new energy industry.

\section{LITERATURE REVIEW}

The concept of financial ecological environment appeared when the ecology system was introduced into the financial field (Bai Qinxian, 2001) [1]. Domestic and foreign scholars mainly study on the impact of financial ecological environment on enterprise performance ( $\mathrm{Yu}$ et al, 2011)[2], capital allocation efficiency (Yan Jiaqi,2015)[3], enterprise investment efficiency (Li Yanxi,2015)[4], financing constraints (Wei Zhihua, 2014)[5] and so on from the perspective of external governance environment. As an emerging industry, the existing literature about new energy industry is mainly concentrated on the financial support mechanism for its development and the factors that affect the financing of new energy industry, while there are few studies directly on the relationship between financial ecological environment and the financing efficiency of new energy industry. Ownership structure refers to the structure of the listed company's equity type and proportion allocation, which is in a fundamental position of corporate governance. LaPorta et al. (1999)[6] believed that equityscattered companies have better financing efficiency than equity-gathered companies. Gomes (2000)[7] used the signaling model and drew a conclusion that ownership concentration is positively correlated with corporate value. The 
focus of western mainstream theory on the relationship between ownership structure and efficiency is mainly on the interest conflict of internal shareholders and external shareholders. Most western scholars believe that too high or too low ownership concentration will adversely affect corporate efficiency, while domestic scholars focus on the relationship between shareholders' share proportion and corporate performance (Zhou Ye'an, 1999)[8], and the influence of controlling shareholders' type on investment efficiency, etc. (Wang Huacheng, 2006)[9]. There is a lack of research on the influence of ownership structure on financing efficiency when it is seen as a whole, and there is no study which considers that the differences in China's regional financial ecological environment may have different incentives for enterprises with different ownership structure, and affect the financing efficiency.

Based on previous studies, this paper takes a sample of listed companies in China's new energy industry, and research on the impact of financial ecological environment and ownership structure on financing efficiency. The main contributions are: (1) On the premise of defining the connotation of financing efficiency, the changing factors of time condition are applied to the generalized DEA method, and the generalized DEA model which is based on panel data is constructed to dynamically measure the financing efficiency of China's new energy industry; (2) We break through the limitations of simple research on financing efficiency, and construct a systematic GMM model by using ecological concept to empirically analyze the impact of financial ecological environment and ownership structure on financing efficiency, and the impact of the differences in regional financial and ecological environment of the East, Central and West on the financing efficiency of the enterprises with different ownership structure, thus we provide a reference for formulating macro policies to promote the development of new energy industry, and provide data support for the optimization of the ownership structure of listed companies in new energy industry.

\section{EVAluAtion OF THE FinANCING EFFICIENCY OF NEW ENERGY INDUSTRY BASED ON PANEL DATA GENERALIZED DEA MODEL}

\section{A. Generalized DEA Model Construction Based on Panel Data}

Data Envelopment Analysis(DEA) is developed by operational researcher Charnes A.\&W.W.Coopers et al. (1978)[10], which is based on the concept of relative efficiency, and it is an important method for evaluating the relative efficiency of similar decision-making units. The similar units have the same goal, task, external environment, and inputoutput indexes. However, when the time condition changes, it will cause changes in the external environment where the decision-making units are located. When the traditional C2R model and BC2model are used to evaluate the panel data information, it will be inconsistent with the applicable conditions of the DEA method, and the evaluation reference system of the traditional DEA method is effective decisionmaking units, it cannot be evaluated on the basis of any reference set. In view of the limitations of the traditional DEA method, Ma Zhanxin (2012)[11] proposed the generalized DEA method, which not only has all the features of the traditional DEA method, but also can be evaluated according to any reference set. On the basis of the generalized DEA method, this paper considers the influence of the changing time condition and constructs a generalized DEA model based on panel data.

It is assumed that $\mathrm{m}$ input indexes and s output indexes are used to reflect the input-output status of a certain class of decision-making units, and the index data of the decisionmaking units on a certain $L$ time series can be measured. If the data of total $\mathrm{n}^{\mathrm{(k)}}$ decision-making units is measured over $\mathrm{k}$ time segments, the input index of the p-th decision-making unit

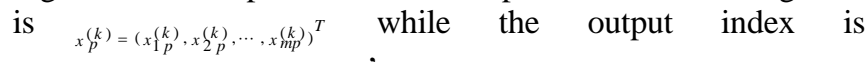
$y_{p}^{(k)}=\left(y_{1 p}^{(k)}, y_{2 p}^{(k)}, \cdots, y_{s p}^{(k)}\right)^{T}$, and $x_{p}^{(k)} \succ 0, y_{p}^{(k)} \succ 0, p=1,2, \cdots, n^{(k)} . k=1,2, \cdots, L$ It is assumed that data of total $\mathrm{n}^{(0)}$ decision-making units is measured in the set time segment, and the input index value corresponding to the $\mathrm{j}$-th decision-making unit is $x_{j}^{(0)}=\left(x_{1 j}^{(0)}, x_{2 j}^{(0)}, \cdots, x_{m j}^{(0)}\right)^{T}$, and the output index value is $y_{j}^{(0)}=\left(y_{1 j}^{(0)}, y_{2 j}^{(0)}, \cdots, y_{s j}^{(0)}\right)^{T}$, and they are all positive numbers. We take the data of the basic time segment as a sample, considering the efficiency of each decision-making unit relative to the basic time segment, and we can construct the production possibility set $\mathrm{T}$ based on the basic time period as $T=\left\{(x, y) \mid x \geq \sum_{j=1}^{n_{j}^{(0)}} \times(\rho) \lambda_{j j}, y \leq \sum_{j=1}^{n_{j}^{(0)}} y_{j}^{(0)} \lambda_{j j}, \delta_{j=1}^{n_{j}^{(0)}} \lambda_{j}=\delta,\left(\lambda_{1}, \ldots \lambda_{n(0)}\right)^{T} \geq 0\right\}$. In the formula (1),If the optimal solution of the DEA-panel satisfies one of the following conditions, (1) $\theta^{0} \succ 1$ or (DEA-panel)there is no feasible solution; (2) $\theta^{0}=1 \mathrm{an} s^{+0}=0, s^{-0}=0$, then the efficiency of the p-th decision-making unit in the k-th time segment is DEA-panel effective.

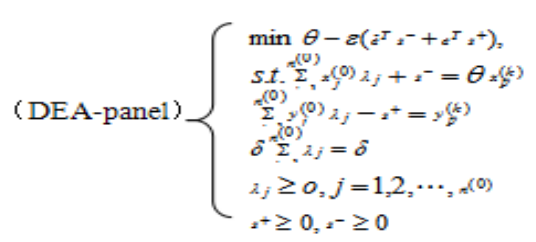

\section{B. Index Selection and Data Sources}

This paper fully draws on the existing research results and considers the applicability, availability, and maneuverability of the selected evaluation indexes. We selected index variables that measure financing cost, financing risk and financing time as input indexes, and chose enterprise profitability, operating capacity and development capacity as output indexes, then the following evaluation index system was constructed, as shown in Table 1.The financing situation of new energy industry from 2010 to 2016 are taken as the research object in this paper. According to the China Securities Regulatory Commission's 2016 Listed Companies Industry Classification Report, industry and removed the stocks with abnormal financial status. A total of 132 listed companies' annual financial data was selected for analysis. If the input and output 
indexes of the decision- making units are negative values, they should be adjusted to be non-negative values.

TABLE I. EVALUATION INDEXES OF FINANCING EFFICIENCY OF CHINA'S NEW ENERGY INDUSTRY

\begin{tabular}{|l|l|l|l|}
\hline Input/Output & Index name & Index variable & Calculation formula \\
\hline \multirow{5}{*}{ Input index } & \multirow{3}{*}{ financing cost } & Cost of debt financing & $\begin{array}{l}\text { Interest expenditure/(Short-term borrowing + Long term } \\
\text { borrowing + Bonds payable) }\end{array}$ \\
\cline { 2 - 4 } & & Cost of equity financing & Capital asset pricing model \\
\cline { 2 - 4 } & Financing risk & Property right ratio & Total liabilities / Total stockholders' equity \\
\cline { 2 - 4 } & Financing time & Speed of financing & Sales income / Net cash inflows of fund-raising activities \\
\hline \multirow{3}{*}{ Output index } & Profitability & Net asset interest rate & Net profit / Asset average \\
\cline { 2 - 4 } & Operational capacity & Total asset turnover & Sales revenue / Asset average \\
\cline { 2 - 4 } & Development capacity & Net profit growth rate & Net profit growth per year / Last year's net profit \\
\hline
\end{tabular}

The data from the RESSRT database, www.cninfo.com.cn

\section{Generalized DEA Model Construction Based on Panel} Data

According to the financing situation of China's new energy industry from 2010 to 2016, the data of each listed company in
2010 was selected as a control group. The financing efficiency of listed companies in China's new energy industry in 20102016 was analyzed by the model (DEA-Panel) through the Matlab software program. The financing efficiency indexes of the listed companies are shown in Table 2 and Figure 1.

TABLE II. FINANCING EFFICIENCY OF CHINA'S NEW ENERGY INDUSTRY FROM 2010 TO 2016

\begin{tabular}{|c|c|c|c|c|c|c|c|}
\hline Years & 2010 & 2011 & 2012 & 2013 & 2014 & 2015 & 2016 \\
\hline Maximum & 1.2705 & 1.2084 & 1.1236 & 1.3276 & 1.2653 & 1.2887 & 1.2339 \\
\hline Minimum & 0.1904 & 0.1628 & 0.1196 & 0.1429 & 0.1647 & 0.1318 & 0.1908 \\
\hline Mean & 0.6071 & 0.6513 & 0.5679 & 0.6032 & 0.6143 & 0.6269 & 0.7068 \\
\hline
\end{tabular}

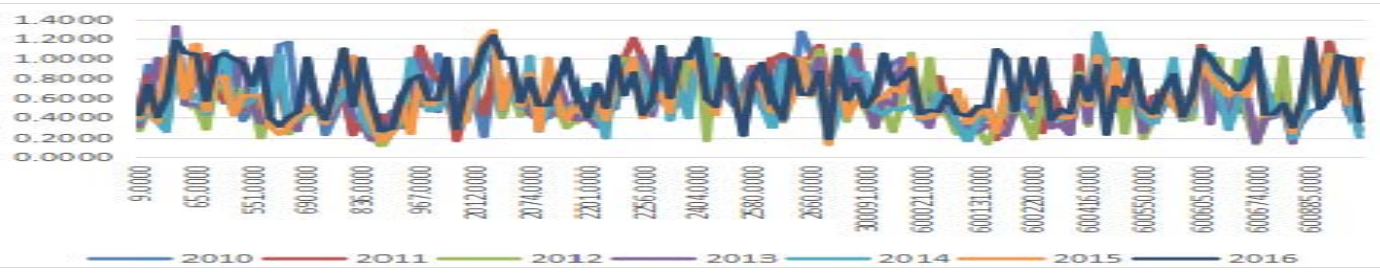

FIGURE I. FINANCING EFFICIENCY OF LISTED COMPANIES IN CHINA'S NEW ENERGY INDUSTRY FROM 2010 TO 2016

It can be seen that the financing efficiency of the 132 listed companies in China's new energy industry from 2010 to 2016 has been hovering around 0.62 , indicating that the financing efficiency of China's new energy industry has not yet reached an effective level from 2010 to 2016. When the level of output is given, the listed companies of new energy industry can further improve efficiency by reducing input. In addition, through the analysis of the changes in the financing efficiency of China's new energy industry from 2010 to 2016, it can be seen that in 2010 and 2011 after the new energy industry was included in the country's strategic emerging industries, the financing efficiency of new energy industry rose rapidly. Because the country has misaligned the target of new energy industry, and local governments are eager to create GDP by relying on new energy industry, serious problems about overcapacity and low financing efficiency showed up in part of the new energy industry. But after 2013, under the government regulation and market adjustment, the new energy industry has gradually embarked on a rational and healthy development track, and the corresponding financing efficiency has also shown an upward trend year by year.

\section{FINANCIAL ECOLOGICAL ENVIRONMENT, OWNERSHIP STRUCTURE AND THE FINANCING EFFICIENCY OF NEW ENERGY INDUSTRY}

Referring to Li Yang (2005)[12], the financial ecological environment evaluation system is composed of multi-levels such as the local economic foundation, the level of financial resources, the legal honest environment, the humanistic social environment, and local government behavior. The influence of ownership structure on financing behavior mainly depends on the type of controlling shareholders and the degree of ownership concentration (Shao Yiping, 2013)[13]. This paper takes the financing efficiency of new energy industry as an explained variable, the financial ecological environment and the ownership structure as explanatory variables to construct a panel data model for regression. Specific index variable system are shown in Table 3. 
TABLE III. INDEX VARIABLE SYSTEM FOR ANALYZING THE RELATIONSHIP BETWEEN FINANCIAL ECOLOGICAL ENVIRONMENT, OWNERSHIP STRUCTURE AND THE FINANCING EFFICIENCY OF NEW ENERGY INDUSTRY

\begin{tabular}{|c|c|c|c|c|}
\hline \multicolumn{2}{|c|}{ V ariab ie tope } & V axiab ienal e & $\begin{array}{l}\text { Variab } \hat{\mathbf{E}} \\
\text { sya bol }\end{array}$ & V ariable descrition \\
\hline $\begin{array}{l}\text { Interpeted } \\
\text { variable }\end{array}$ & $\begin{array}{l}\text { Finanging } \\
\text { efficiency }\end{array}$ & Financingefficiency & $T E$ & A bovefinancing efficiency \\
\hline \multirow{7}{*}{$\begin{array}{l}\text { Explanatory } \\
\text { variable }\end{array}$} & \multirow{5}{*}{$\begin{array}{l}\text { Financil } \\
\text { ecological } \\
\text { envitorment }\end{array}$} & Ecnon ic base & EB & $\begin{array}{l}\text { The percaita GD P (En thousandyuan) of the con pany's } \\
\text { lo cation }\end{array}$ \\
\hline & & L evelo f fnancilresources & $F R$ & $\begin{array}{c}\text { The to an bain of of the financil institution in the } \\
\text { con pany's location (trillion yuan) }\end{array}$ \\
\hline & & L egalhanestenviom ent & $\mathrm{LH}$ & $\begin{array}{c}\text { The num ber of lar yersp er } 10,000 \text { people. In the con pany's } \\
\text { location (people) }\end{array}$ \\
\hline & & $\begin{array}{c}\text { H un anistic sociel } \\
\text { em inonm ent }\end{array}$ & HS & $\begin{array}{c}\text { The number ofschool teachers per 10,000 people in the } \\
\text { con pan's location (people) }\end{array}$ \\
\hline & & L ocalgovernm entbehavior & GH & Percapita fiscalexpenditure (ten fhousandyuan) \\
\hline & \multirow[b]{2}{*}{$\begin{array}{l}\text { ornership } \\
\text { stucture }\end{array}$} & $\begin{array}{l}\text { The characteristics of } \\
\text { conto ling sharehoider }\end{array}$ & $\operatorname{cs}$ & $\begin{array}{l}\text { If the contolling shareho ideris stater on ned, the varid le is } 1 \text {, } \\
\text { of ther ise } 0 .\end{array}$ \\
\hline & & 0 mership concen tation & $O C$ & 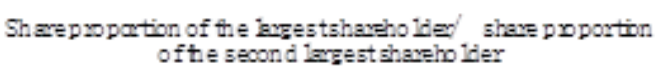 \\
\hline \multirow{2}{*}{$\begin{array}{l}\text { Contol } \\
\text { variable }\end{array}$} & & Entexprise size & SIZE & T otalasets of the con pary (billion yuan) \\
\hline & \multicolumn{2}{|c|}{ A nnualduma y variable } & YERA & $\begin{array}{l}\text { The in pacto fu acro econom is conto lby using the } 2010 \text { as } \\
\text { the bae } y \in a x\end{array}$ \\
\hline
\end{tabular}

The data from the RESSRT database, 2010-2016 annual reports and official website disclosures of 132 listed companies, 2010-2016 statistical yearbooks of provinces and cities where the listed company is registered.

\section{A. Model Setting}

Because the data of relevant index variables of the 132 listed companies in China's new energy industry during 20102016 constitutes short-panel data, the unit root test and cointegration test results of relevant data show that regression analysis can be performed. Considering that financing efficiency will be affected by its own lag, the system GMM model proposed by Blundell and Bond (1998)[14] is used to loosen the limitation that the random error term must obey the dynamic distribution, and it is not necessary to consider related problems about interscholastic and sequences. Therefore, the obtained parameter estimators are more effective and reliable, and the specific model form is set as shown in formula (2), Where C is a constant term, ${ }_{\beta}$ is a coefficient variable, and ${ }_{\varepsilon_{i t}}$ is a random error term.

$$
T E_{i t}=C+\beta_{0} T E_{i(t-1)}+\beta_{1} \ln E B_{i t}+\beta_{2} \ln F R_{i t}+\beta_{3} \ln L H_{i t}+\beta_{4} \ln H S_{i t}+\beta_{5} \ln G H_{i t}+\beta_{6} C S_{i t}+\beta_{7} \ln O C_{i t}+\beta_{8} \ln S I Z E_{i t}+\sum Y e a r+\varepsilon_{i t}
$$

\section{B. Empirical Analysis}

According to the index variable system of the relationship between financial ecological environment, ownership structure and the financing efficiency of new energy industry which is constructed in Table 3.After the regression on model (2) by running Stata software program, the results can be seen in Table 4. In order to study on that the differences in China's regional financial ecological environment may generate different incentives on different companies with different ownership structure and affect the financing efficiency, 132 listed companies of China's new energy industry are divided into the eastern, central and western regions in accordance with the company's location, and they are substituted into model (2) respectively for systematic GMM estimation. The regression results are shown in Table 5 . At the same time, in order to ensure the robustness of the regression model, an alternative regression test is used for some indexes of the financial ecological environment and ownership structure. For example, the financial institution loan balance index which can measure the level of financial resources is replaced with the balance of deposits and loans of financial institutions in the company's location. The per capital fiscal expenditure index which can measure the local government behavior is replaced by the budgetary and extra-budgetary fiscal expenditure/GDP in the company's location, and the share proportion of the largest shareholder to the second largest shareholder that measures the ownership structure is replaced by the share proportion of the top five shareholders. Through the study and comparison, it can be found that there is no significant difference in the results of the model.

TABLE IV. PANEL ESTIMATION RESULTS OF THE FINANCIAL ECOLOGICAL ENVIRONMENT AND OWNERSHIP STRUCTURE ON THE FINANCING EFFICIENCY

\begin{tabular}{|c|c|c|c|c|c|c|}
\hline C & TEt-1 & $\ln E B$ & $\operatorname{lnFR}$ & $\operatorname{lnLH}$ & $\operatorname{lnHS}$ & $\operatorname{lnGH}$ \\
\hline $\begin{array}{l}-1.066^{*} \\
(0.542) \\
\end{array}$ & $\begin{array}{c}0.069^{* * *} \\
(0.000)\end{array}$ & $\begin{array}{c}0.104 * * * \\
(0.122) \\
\end{array}$ & $\begin{array}{c}0.072^{* *} \\
(0.045) \\
\end{array}$ & $\begin{array}{c}-0.019 \\
(0.113) \\
\end{array}$ & $\begin{array}{l}0.005^{*} \\
(0.186)\end{array}$ & $\begin{array}{c}-0.057^{* *} \\
(0.175)\end{array}$ \\
\hline $\mathrm{CS}$ & $\operatorname{lnOC}$ & $\operatorname{lnSIZE}$ & $\mathrm{AR}(1)$ & $\mathrm{AR}(2)$ & Sargan-test & \\
\hline $\begin{array}{c}-0.041^{* *} \\
(0.054) \\
\end{array}$ & $\begin{array}{c}-0.055^{* *} \\
(0.264) \\
\end{array}$ & $\begin{array}{c}0.024^{* *} \\
(0.174) \\
\end{array}$ & 0.075 & 0.336 & 0.325 & \\
\hline
\end{tabular}

***,** and * respectively indicate significance at the level of $1 \%, 5 \%$ and $10 \%$, Sargan test AR(1) and AR(2) tests allgive significant p-value 
TABLE V. PANEL ESTIMATION RESULTS OF THE FINANCIAL ECOLOGICAL ENVIRONMENT AND OWNERSHIP STRUCTURE OF THE EASTERN, CENTRAL AND WESTERN REGIONS ON THE FINANCING EFFICIENCY OF NEW ENERGY INDUSTRY

\begin{tabular}{|c|c|c|c|}
\hline The location of the listed companies & The eastern region & The central region & The western region \\
\hline $\mathrm{C}$ & $\begin{array}{l}0.387^{* *} \\
(0.506)\end{array}$ & $\begin{array}{l}0.538^{* *} \\
(0.752)\end{array}$ & $\begin{array}{l}-1.262^{*} \\
(0.836)\end{array}$ \\
\hline $\mathrm{TE}_{\mathrm{t}-1}$ & $\begin{array}{c}0.071^{* * *} \\
(0.036)\end{array}$ & $\begin{array}{c}0.066^{* * *} \\
(0.032)\end{array}$ & $\begin{array}{c}0.058^{* * *} \\
(0.048)\end{array}$ \\
\hline $\ln E B$ & $\begin{array}{c}0.115^{* * *} \\
(0.052) \\
\end{array}$ & $\begin{array}{c}0.064 * * * \\
(0.074)\end{array}$ & $\begin{array}{l}0.056^{* *} \\
(0.035) \\
\end{array}$ \\
\hline $\ln F R$ & $\begin{array}{c}0.062 * * * \\
(0.037) \\
\end{array}$ & $\begin{array}{l}0.065^{* *} \\
(0.012) \\
\end{array}$ & $\begin{array}{l}0.078^{* *} \\
(0.014) \\
\end{array}$ \\
\hline $\operatorname{lnLH}$ & $\begin{array}{c}0.023 \\
(0.162)\end{array}$ & $\begin{array}{c}-0.018^{*} \\
(0.095)\end{array}$ & $\begin{array}{c}-0.023 \\
(0.179)\end{array}$ \\
\hline $\ln H S$ & $\begin{array}{c}0.009^{* *} \\
(0.058)\end{array}$ & $\begin{array}{l}0.006^{*} \\
(0.062)\end{array}$ & $\begin{array}{l}-0.003^{*} \\
(0.034)\end{array}$ \\
\hline $\operatorname{lnGH}$ & $\begin{array}{c}-0.061 * * \\
(0.027) \\
\end{array}$ & $\begin{array}{c}-0.058^{* *} \\
(0.014)\end{array}$ & $\begin{array}{l}0.055^{* *} \\
(0.081) \\
\end{array}$ \\
\hline CS & $\begin{array}{c}-0.069 * * \\
(0.022) \\
\end{array}$ & $\begin{array}{c}-0.032^{* * *} \\
(0.013)\end{array}$ & $\begin{array}{l}0.049^{* *} \\
(0.034)\end{array}$ \\
\hline $\operatorname{lnOC}$ & $\begin{array}{c}-0.076^{* *} \\
(0.025) \\
\end{array}$ & $\begin{array}{c}-0.062 * * \\
(0.004) \\
\end{array}$ & $\begin{array}{c}0.046^{* * *} \\
(0.064)\end{array}$ \\
\hline lnSIZE & $\begin{array}{l}0.025^{* *} \\
(0.043) \\
\end{array}$ & $\begin{array}{l}0.021^{*} \\
(0.036) \\
\end{array}$ & $\begin{array}{c}0.027 * * * \\
(0.045) \\
\end{array}$ \\
\hline AR(1) & 0.044 & 0.027 & 0.032 \\
\hline AR(2) & 0.217 & 0.302 & 0.533 \\
\hline Sargan-test & 0.346 & 0.228 & 0.305 \\
\hline
\end{tabular}

\section{Empirical Results}

By analyzing the panel results in Tables 4 and 5, it can be seen that the parameter estimates for the financing efficiency of China's new energy industry after a period of lag are significantly positive, which indicates that the financing efficiency of new energy industry has obvious inertial effect and cumulative effect over time, namely the improvement of the current financing efficiency will help the development of new energy industry in subsequent years. The result of analyzing the impact of the financial ecological environment on the financing efficiency of new energy industry shows that the developed economy and financing environment can significantly promote the financing efficiency of new energy industry, the behavior of local government has different effects on the financing efficiency of new energy industry in different regions. The expansion of fiscal expenditure in the eastern and central regions will inhibit the improvement of the financing efficiency of new energy industry to some extent. This, to a certain extent, can explain the large leap forward in the development of fractional new energy industry around 2012, which was caused by the stimulus of the government's high subsidies, but it also caused the financing efficiency of new energy industry to decline. The behavior of local government in the western region can positively adjust the financing efficiency of new energy industry. The reason may be that the development of new energy industry in economically and financially backward areas is still mainly dependent on the government's support, and the ability of capital market allocation is relatively weak. The correlation among the Legal honest environment, humanistic social environment and the financing efficiency of new energy industry is not prominent. This shows that the overall legal honest and humanistic social systems in China do not have a significant impetus for the development of new energy industry, and the development path of new energy industry has not yet been switched to the way which is dominated by human capital and technical resources. In terms of the impact of ownership structure on the financing efficiency of new energy industry, the financing efficiency of the non-state-owned new energy listed companies in the eastern and central regions is higher than that of state-owned new energy listed companies. The new energy listed companies with relatively dispersed equity are more efficient in financing, but the estimation result in the west region is just the opposite. The state-owned new energy listed companies with concentrated ownership have the highest financing efficiency. To some extent, this proves that the development of new energy industry in the western region depends more on government behavior than on the will of the market. After comprehensively analyzing the impact of asset size control variables, it can be concluded that the financing efficiency of listed companies with a relatively large asset size has certain advantages.

\section{SugGESTIONS}

To sum up the above empirical research conclusions, in order to effectively lift the financing efficiency of China's new energy industry, it is necessary to combine the regional financial ecological environment and the differences in the ownership structure of enterprises to further improve the benign development mechanism of the capital financing and scientific allocation of new energy industry. We should also further improve the scientific nature of government industrial support policies in the eastern and central regions and increase the service consciousness of government departments. In the western region, we need to consider strengthening the ability of capital market allocation and promote new energy 
companies with development potential to become bigger and stronger. At the same time, we should continue to strengthen the economic base and financial resources construction, provide state-owned and private enterprises with a fair competition environment, and accelerate the establishment of a multi-user capital market which is fully-fledged and highly efficient. It is also important to encourage new energy industry to broaden financing channels, carry out financing innovations, and improve the establishment of the legal honest environment and humanistic social environment system in order to form a powerful impetus for the promotion of new energy industry, Also we need to improve corporate governance, optimize the ownership structure and financing structure of enterprises, increase the power of human resources training and technological innovation researching, and support the healthy and sustainable development of new energy industry by promoting scientific management, technological innovation and scale expansion.

\section{ACKNOWLEDGMENT}

This research is supported by National Social Science Foundation of China (15BGL056), funded by Qing Lan Project in Jiangsu Province(2016), Key Projects from Philosophy and Social Science Fund of Universities in Jiangsu Province (2015ZDIXM008), Fund Projects from Philosophy and Social Science Fund of Universities in Jiangsu Province (2017SJB2058), Fundamental Research of Nanjing Institute of Technology(JCYJ201622),Doctoral Research Funding Projects of Nanjing Institute of Technology(ZKJ201512).

\section{REFERENCES}

[1] Bai Qinxian, Introduction to Sustainable Financial Development, Beijing: China Financial Publishing House, 2001.

[2] YU W,ZHENG Y, "Government regulation, corporate board, and firm value: Evidence from China”, Journal of International Financial Management and Accounting ,vol.25, pp. 182-208,2011.

[3] Qi Jiaqi, Shao Xinjian, "Cross-listing, government intervention and capital allocation efficiency”, Economic Research, vol.6, pp. 117-130, 2015 ,

[4] Li Yanxi, Zeng Weiqiang, Ma Zhuang et al, "External governance environment, nature of property rights, and efficiency of listed company investment”, Nankai Business Review, vol.18, pp: 25- 36, 2015.

[5] Wei Zhihua, Zeng Aimin, Li Bo, "Financial Eco-environment and Corporate Financing Constraints: An Empirical Study Based on Chinese Listed Companies”, Accounting Research, vol.5, pp: 73-80, 2014.

[6] La Porta R, Lopez-de-Si lanes, and A. Shleifer, "Corporate Ownership around the world”, Journal of Finance, vol.2, pp: 471-517, 1999.

[7] Gomes A, and W. Novaes, "Multiple Larges Shareholdes and Corporate Governance”, The Wharton School: University of Pennsylvania, 1999.

[8] ZHOU Ye-an, "Empirical Study on the Impact of Financial Suppression on the Financing Capacity of Chinese Enterprises”, Economic Research, vol.2, pp: 15-22, 1999.

[9] Wang Huacheng, Yan Yan., "Controlling Shareholders and Earnings Quality: An Empirical Study Based on Earnings Response Coefficients”, Accounting Research, vol.2.pp: 66-74+97, 2006.

[10] Charnes A., Coopers W.W., Rhodes, "Measuring the Efficiency of Decision Making Units", European Journal of Operational Research., vol.2, pp: 429-444, 1978.

[11] Ma Zhanxin, Ma Shengyu, Bao Siqin Gao Wa., Data Envelopment Analysis and Its Application Cases, Beijing: Science Press, 2013.
[12] Li Yang, Wang Guogang, Liu Yihui, Evaluation of China's urban financial ecological environment, Beijing: People's Publishing House, 2005.

[13] Shao Yiping, Zhang Hao, "Macroeconomic Fluctuations, Ownership Structure and Financing Preference", Collected Essays on Finance and Economics, vol.5, pp: 88-94, 2013.

[14] Blundell and Bond, "Initial conditions and moment restrictions in dynamic panel data models”, Journal of Econometrics, vol.87, pp: 115143, 1998. 